\title{
A Sense of Europe: The Making of this Continent in Early Modern Dutch News Media
}

\author{
Joop W. Koopmans*
}

During the Middle Ages many European authors employed the word Christianitas - or vernacular synonyms such as, in English, Christianity or Christendom - instead of the geographical notion 'Europe' to identify their continent. Although medieval geographers continued to use the word 'Europe', an essentially neutral term at the time, the Roman Catholic Church was particularly influential in promoting the word Christianitas. The Catholic clergy hoped to make clear that Europe was a Christian world and Europeans were Christians. As Denys Hay concluded in his pioneering introduction to Europe as an idea, in this era the term Europe was "devoid of sentiment", while Christendom was "a word with profound emotional overtones". Christianity was the bulwark against the threatening world of Muslims who had conquered the Holy Sepulchre in Jerusalem, but it also represented the comfort and familiarity of home, far removed from the exotic, alien and largely unknown regions of Asia and Africa. This helps to explain why Christianitas and Christendom came into common use, while the term Europe remained comparatively rare. ${ }^{1}$

However, during the Renaissance the meaning and idea of Europe changed. Humanists made synonyms of the words Christianitas and Europe by granting an emotional content to the latter. Gradually Europe became a more popular word than Christendom as a name for the European continent. A variety of reasons may explain this change, three of which will be briefly touched on here. In the first place, since the Late Middle Ages Christianity was no longer a unified entity, ruled by the pope in spiritual matters and the Emperor in the secular sphere. Europe consisted by this time of several important states, and their princes challenged the papal and imperial authorities. Secondly, in 1453 the Ottomans conquered the Byzantine capital of Constantinople, and occupied an important part of the Christian world. Although this area was Greek Orthodox, and regarded as very different from the Latin version of Christianity,

* I wish to thank my colleague Anjana Singh for her stimulating remarks.

1 Denys Hay, Europe: The Emergence of an Idea (Edinburgh: Edinburgh University Press, 1957), pp. 22-3, 27-30, 58 (quote); Heikki Mikkeli, Europe as an Idea and an Identity (Basingstoke: Palgrave, 1998), pp. 22-31.

(C) JOOP W. KOOPMANS, 2016 | DOI 10.1163/9789004277199_027

This is an open access chapter distributed under the terms of the Creative Commons Attribution-

Noncommercial-NoDerivatives 3.o Unported (CC-BY-NC-ND 3.0) License. 
it was considered as an essential part of Europe because of its Greek heritage. In the third place, Martin Luther's Reformation ended the unity of the Latin Christian world. Something new was needed to mobilise the people of Europe and unite them, for instance, in their struggle against the advancing Ottomans. In this conflict, which did not end until the eighteenth century, the concept of Europe fitted better than the idea of a single Christianitas.

The Italian humanist Enea Silvio Piccolomini was already strongly aware of this need for a new unity. He became pope in 1458 , only five years after the fall of Constantinople. As Pope Pius III he wished to reconquer the former Byzantine capital and he felt that he had to use a new ideology to create unity among the inhabitants of his continent. According to him Europe had to become the new word for 'our homes'. Yet in Pius's eyes, Europeans were still Christians, and most people would stick to this view during the next centuries. However, the words 'Europeans' and 'Christians' did not remain synonyms, mainly because of European interaction with other continents, which led to the spread of Christianity worldwide. As a result of this development we can discern another process. The so-called 'Age of Discovery' led to the controversial idea that Europeans inhabited a civilised world, in contrast with the 'despotic' world of Asians and the 'barbarian' world of Africans and Native Americans. According to this mindset Europe was synonymous with civilisation, and the European elites esteemed their own society as the summit of human achievement.

As is well known, the printing press was one of the most important tools to disseminate and propagate ideas of 'us' and 'them' to a wide and growing audience across Europe. Most early modern Europeans would never travel outside their own region. Nevertheless, they could obtain a better understanding of their continent through a variety of printed media which kept them increasingly informed about what happened in their own continent, as well as other parts of the world visited by a small group of fellow Europeans. Several European news networks emerged to supply this information, and those networks were linked by improving postal systems, as well as by trade and diplomatic contacts. ${ }^{2}$ Printed news media induced curiosity, spread knowledge in wider circles than before, and elicited specific responses to the news topics on which they reported. It seems clear that printed news media contributed to the construction of a European identity during the period in which other continents came increasingly into the consciousness of Europe's citizens. The issue is how this happened, and whether and to what extent it was intentional.

2 Peter Rietbergen, Europe: A Cultural History (1998; London and New York: Routledge, 2006), pp. 190-91, 208-36; Jacques le Goff, The Birth of Europe (Oxford: Blackwell, 2005), pp. 1-5, $177-86$. 
This chapter reflects on the European character of seventeenth- and eighteenth-century Dutch news media. It will function as a case study in the emergence of the concept of Europe and address the following questions: how might the content and layout of printed newspapers and news periodicals (here defined as those with less than weekly frequency) have affected the idea and construction of Europe among Dutch readers, and how did those media mirror or stimulate a sense of Europe? I will answer these questions by discussing several arguments, first by concentrating on the visible presence of the words 'Europe' and 'European' in the titles and contents of Dutch news media, where news items from other European countries predominated and relatively little attention was paid to domestic affairs. Furthermore, the European character of those media will be demonstrated through their layout, which was a vital element in shaping readers' perceptions, drawing their attention to reports published under the headings of European state names and cities. Finally, the allegorical presence of Europe in news prints - as Princess Europa-will be discussed, to show that these fashioning processes were not simply textual.

\section{Argument One: Europe in Dutch News Media Titles}

The publishers of the first printed European news media did not give very imaginative titles to their issues. Yet most titles would reveal their place of origin or give an idea of their content. The first printed Dutch newspaper, for example, was Caspar van Hilten's 1618 Courante uyt Italien, Duytslandt \&cc, a title that suggested paragraphs of news from Italy, Germany and other European countries. The habit of naming a newspaper or periodical after the city where it was published became very widespread, such as the Gazzetta di Mantova, printed in the Italian city of Mantua from 1664, the London Gazette, an official newspaper launched in 1665 as the Oxford Gazette, or the Wiener Zeitung, the newspaper of the Austrian capital that began life as the Wienerisches Diarium.

However, several publishers or editors contrived titles in which the noun 'Europe' or the adjective 'European' was included. A few early English examples are $A$ true relation of the affaires of Europe (1622) and The newes and affaires of Europe (1624), both published in London. ${ }^{3}$ By choosing such titles the editors

3 The rest of this title, printed for Nathaniel Butter and Nicholas Bourne, revealed more about the content: especially, France, Flanders, and the Palatinate. Whereby you may see the Present Estate of her Provinces, and Conjecture what these Troubles and Wars may Produce etc. These 
probably tried to reach an audience and create a market that extended beyond the local citizens. In any case they indicated that news from different European corners would be presented in the columns. Only the title words' language made clear for which group these media were meant. This was not the case with linguistic regions, as newspapermen could and did publish their wares in different languages. Around 1700, for example, the French newspaper Histoire journalière de ce qui se passe de plus considerable en Europe was published in The Hague, thus not in France or another French-speaking region. ${ }^{4}$

One of the first Dutch news prints with 'Europe' or 'European' in the title was the Europische Courant, an Amsterdam newspaper of which copies survive for the period $1642-1646.5$ Mathijs van Meininga published this coranto three times a week, an unusual periodicity for the time as most Dutch newspapers appeared weekly or twice a week at most. In 1645 Van Meininga's Amsterdam competitor Jan Jacobsz Bouman published the Extra Europische tijdingen uyt verscheijde Quartieren (Extra European tidings from various Quarters), twice a week. ${ }^{6}$ Another example is the Wekelycke Mercurius van alle het gedenckwaerdigste dat door geheel Europa passeert (Weekly Mercury of all the most noteworthy things happening throughout the whole of Europe), a newspaper published in The Hague in 1654 by Johannes Rammazeyn, but suppressed after only thirteen issues, perhaps because of the editor's political position. ${ }^{7}$ Another attempt to establish a newspaper in The Hague was the Haegsche Weeckelicke Mercurius, vervattende alle gedenckweerdigste advysen van geheel Europa (The Hague Mercury, including complete and most noteworthy accounts of allEurope), printed by Christianus Calaminus in 1656-1658. This newspaper too had a rather short

and other examples are discussed in, e.g., Nicholas Brownlees, 'Narrating Contemporaneity: Text and Structure in English News' in The Dissemination of News and the Emergence of Contemporaneity in Early Modern Europe, ed. Brendan Dooley (Farnham and Burlington: Ashgate, 2010), pp. 225-50, at 231-41.

4 Ingrid Maier and René Vos, 'Van oude couranten de dingen die opduiken: Nieuw licht op de Haagse pers in de zeventiende eeuw', in Jaarboek Die Haghe (The Hague: Geschiedkundige Vereniging Die Haghe, 2004), pp. 10-35, at 28.

5 'Europisch' and 'Europische' are old Dutch adjectives for European; the modern Dutch variants are 'Europees' and 'Europese'.

6 Otto Lankhorst, 'Newspapers in the Netherlands in the Seventeenth Century' in The Politics of Information in Early Modern Europe, ed. Brendan Dooley and Sabrina A. Baron (London: Routledge, 2001), pp. 151-9, at $15^{2}$.

7 Rammazeyn was an Orangist while the anti-Orangist regents were in power at the time. I am grateful to Rietje van Vliet for inspection in several entries of the Encyclopedie Nederlandstalige tijdschriften $(E N T)$ — forthcoming: see < ent1815.wordpress.com/>[03/05/15]—in this case her entry 'Wekelycke Mercurius (1654)'. 
life. It was suppressed after its editor, Gerard Lodewijk van der Maght, had published false news. For this he was banished from Holland for ten years. ${ }^{8}$

During the next decade Van der Maght continued his editorial activities in the city of Utrecht, composing the columns of the Ordinaire Donderdaeghse Europische Courant (Ordinary Thursday European Coranto) between 1660 and 1667 under a false name. This was not much help to him, as his Utrecht title was also censored for reporting erroneous news. ${ }^{9}$ Meanwhile, in 1656, the Haarlem editor Abraham Casteleyn had started the Weeckelycke (weekly) courante van Europa. After a few years, however, he had to change the title when he began putting out a second number each week. Casteleyn's new titles included the name of his city, becoming Haerlemse Dingsdaegse (Tuesday) Courant and Haerlemse Saterdaegse (Saturday) Courant. This newspaper became one of the leading titles in the Dutch Republic and was read all over Europe, in Dutch as well as in several translations. ${ }^{10}$

All the above-mentioned Dutch newspapers with the words 'Europe' or 'European' in their titles were either relatively short-lived, or shed them after a short period. Nonetheless, they demonstrate that Dutch publishers expected titles including the words 'Europe' and 'European' to be commercially attractive. Otherwise they would not have copied earlier titles or made variations, as in the 1690 case of the Amsterdam Europische Mercurius. This long-running news periodical, which existed until 1756, putting out about 300 pages in quarto every six months, probably derived its title from the German magazine Europäischer Mercurius, oder Götterboth of 1689. The Amsterdam publisher Timotheus ten Hoorn started his Dutch Europische Mercurius in the same year as the English author John Philips began his monthly review The Present State of Europe, or a Historical and Political Mercury. ${ }^{11}$ We may thus conclude that

8 Van der Maght (or Macht) was probably also involved in the Wekelycke Mercurius etc. Maier and Vos, 'Van oude couranten', 25-7; Ingrid Maier, 'Zur Frühgeschichte der Haager Zeitungen', Quaerendo, 34 (2004), pp. 87-133, at 113-29.

9 From the last mentioned title only a few copies have survived. Gerrit Albert Evers, 'De Utrechtse "Nieuwstijding” "Mercurius" en "Europische Courant”, De Tampon 20 (1940), pp. 1-17, at $5^{-12}$.

10 From 1662 the word 'Oprechte' (sincere) preceded these titles, which meant that this was the only officially excepted newspaper from the city of Haarlem. Ingrid Maier and René Vos, 'Gelezen van Londen tot Moskou: Internationale dimensies van de Oprechte Haerlemsche Courant in de zeventiende eeuw', in: Haerlem Jaarboek 2005 (Haarlem: Historische Vereniging Haerlem, 2006), pp. 9-33, at 10, 14-16.

11 About the Europische Mercurius, see, e.g., the literature mentioned in my article "Storehouses of news": The Meaning of Early Modern News Periodicals in Western Europe', in Not Dead Things: The Dissemination of Popular Print in England and Wales, 
Europe was in the publishers' and editors' minds towards the end of the century. In 1692-1702 'Europe' was also part of the title of Pieter Rabus' scholarly periodical De boekzaal (library) van Europe, further evidence that publishers presumed that the continent's name represented a strong selling point. ${ }^{12}$

At the end of the seventeenth century the use of 'Europe' or 'European' seems to have become more common in news periodicals' titles than in newspapers' titles. This is not surprising when we consider that far more newspapers than news periodicals existed. Thus greater variety was needed in the first category's titles to distinguish them from each other. During the next century 'Europe(an)' would be mainly included in new Dutch news periodicals' titles, such as 't Ontroerd' Europa (Disturbed Europe). According to the only surviving issue of this periodical, predominantly containing war news from Italy, France, England, Poland and the Netherlands, it would become a weekly that would have been bound every month. ${ }^{13}$ Examples of long-running eighteenth-century titles are the monthly news periodicals De Europische staats-secretaris (state secretary) (1741-c. 1784), its successor Denieuwe Europische staats-secretaris (c. 1785-1806), ${ }^{14}$ and Het verward (confused) Europa (1742-45), which appeared every two months. The main topic of this last was the War of the Austrian Succession, an international conflict in which the most important European countries were involved..$^{15} \mathrm{~A}$ final interesting example is the anti-Orangist Courier van Europa $(1783-5)$, which appeared during the struggle between Orangists and their opponents who were called Patriots. This magazine was filled with observations

Italy, and the Low Countries, 1500-1820, ed. Roeland Harms, Joad Raymond and Jeroen Salman (Leiden: Brill, 2013), pp. 253-73, at 262 and 268; about the Europäischer Mercurius: Johannes Weber, Götter-Both Mercurius: die Urgeschichte der politischen Zeitschrift in Deutschland (Bremen: Temen 1994), pp. 125-39.

12 Peter Rietbergen, 'Pieter Rabus en de Boekzaal van Europe' in Pieter Rabus en de Boekzaal van Europe 1692-1702, ed. Hans Bots (Amsterdam: Holland University Press, 1974), pp. 1-109; J.J.V.M. de Vet, Pieter Rabus (1660-1702) (Amsterdam and Maarssen: Holland University Press, 1980), pp. 122-144 and passim. See also the site 'Early Enlightenment in a Rotterdam Periodical 1692-1704', <www.eerp.nl/> [03/05/15]. An eighteenth century scholarly periodical with 'Europe' in the title was Uitgezogte verhandelingen uit de nieuwste werken van de Societeiten der Weetenschappen in Europa en van andere geleerde mannen (Selected treatises from the latest works of the Academic Societies in Europe and other scholars; 1755-1765). R. van Vliet's entry 'Uitgezogte verhandelingen $\left(1755^{-1765}\right)$ ', to be published in ENT.

13 A. Hanou's entry 't Ontroerd Europa (1701)', to be published in ENT.

14 The first was printed in Haarlem, by Izaak and Johannes Enschedé who also printed the Oprechte Haerlems[ch] C Courant from 1737; the second in Amsterdam by Dirk Swart and Isaak Scholten.

15 Published in Haarlem by Jan van Lee. Only the short title is given here. See A. Hanou's entry 'Verward Europa (1742-1745)', to be published in ENT. 
about domestic and international politics of the time, written by Willem van Irhoven van Dam, an anti-Orangist. Thus this was not so much a news periodical as a periodical series of personal reflections on the news. ${ }^{16}$

The early modern newspapers and periodicals with 'Europe' or 'European' in their titles were only a small part in the long list of early modern Dutch news media. This indicates that they reached a marginal section of the reading public. It would therefore be unwise to over estimate their contribution to the creation of a sense of Europe in the Dutch Republic. Their role in this has to be combined with other considerations relevant to all titles.

\section{Argument Two: Europe in Dutch Newspapers' Content}

The words 'Europe' and 'European' could of course also be found in the contents of news media, regardless of whether they featured the terms in their titles. Subsequent questions might be, first how often, and second in which contexts and in what sense news editors used 'Europe(an)' in their news accounts. Unfortunately the first question is impossible to answer satisfactorily. Useful statistical information cannot be easily generated as many early modern Dutch series of news media are incomplete-in particular those of the seventeenth century—and not all available issues have yet been digitised and the numbers of digitised pages or words in those copies that have been is unknown.

Nevertheless, it is tempting to give a rough impression based on the 85,069 individual issues of early newspapers digitised by the Dutch Royal Library (Koninklijke Bibliotheek) as of October 2013. ${ }^{17} \mathrm{~A}$ text retrieval with the Dutch designation 'Europa' leads to the conclusion that newspapers' editors rarely used this word in the digitised copies prior to 1660 (see Table 26.1). Yet we have to keep in mind that few newspapers existed in that period, and that the number of newspapers, their printed copies and their issues per week would steadily increase thereafter. Over the next two decades, $1660-1680$, the figures increase to several dozen, between 1680 and 1720 to a few hundred and later to

16 Peet Theeuwen, 'Kringen rond een patriots intellectueel: Willem van Irhoven van Dam en zijn 'Courier van Europa' (1783-1785)' in Periodieken en hun kringen: Een verkenning van tijdschriften en netwerken in de laatste drie eeuwen, ed. Hans Bots and Sophie Levie (Nijmegen: Van Tilt, 2006), pp. 129-47. Other eighteenth-century examples are: De Europische reiziger: of de geest der nieuwstydingen (The European Traveller: Or the Spirit of News Tidings; 1777), De Post van Europa (1782), Europa op het einde der agttiende eeuw (Europe at the End of the Eighteenth Century; 1790) and Dagboek van (Diary of) Europa (1792-1793). See A. Hanou's entries, to be published in ENT. 
TABLE 26.1 Frequency of the word 'Europa' in the copies of Dutch newspapers digitised by the Koninklijke Bibliotheek (Royal Library) in The Hague, The Netherlands, compared with the frequency of the word 'Portugal' (also spelled as 'Portugael' and 'Portugaal'), a country that was far less in the news than all the neighbouring countries of the Dutch Republic.

Seventeenth Century

Years Digitised Europa Portugal Years

\section{Eighteenth Century}

\author{
Digitised Europa Portugal \\ copies
}

\begin{tabular}{|c|c|c|c|c|c|c|c|}
\hline \multicolumn{4}{|c|}{ Dutch printed newspapers start in 1618} & $1700-1709$ & 4260 & 417 & 2700 \\
\hline $1618-1619$ & 11 & $\mathrm{o}$ & $\mathrm{O}$ & $1710-1719$ & 2392 & 248 & 1238 \\
\hline $1620-1629$ & 184 & 1 & 2 & $1720-1729$ & $55^{8} 3$ & 1083 & 2578 \\
\hline $1630-1639$ & 123 & 1 & $\mathrm{o}$ & $1730-1739$ & 5931 & 1598 & 2670 \\
\hline $1640-1649$ & 618 & 1 & 2 & $1740-1749$ & 6536 & 2780 & $15^{17}$ \\
\hline $1650-1659$ & 166 & 2 & o & $1750-1759$ & 6362 & 1860 & 1910 \\
\hline $1660-1669$ & 696 & 12 & 273 & $1760-1>69$ & 8936 & 2308 & 2363 \\
\hline $1670-1679$ & 2112 & 53 & $45^{1}$ & $1770-1779$ & 9482 & 2885 & $15^{13}$ \\
\hline $1680-1689$ & 1395 & 212 & $35^{2}$ & $1780-1789$ & $1215^{1}$ & 4731 & 1234 \\
\hline $1690-1699$ & 2747 & 190 & 836 & $1790-1799$ & 15384 & 4862 & 1192 \\
\hline total & $805^{2}$ & 472 & 1916 & total & 77017 & 22772 & 18915 \\
\hline
\end{tabular}

many thousand. One conclusion that can reliably be derived from these figures is that Dutch newspapers' readers were occasionally confronted with the name of their continent. We should also be aware that as well as featuring the noun 'Europe', these papers also frequently contained the Dutch variants for 'European'. A text search for such adjectives 'Europe(e)s(e)', 'Euroops(e)' and 'Europisch(e)' also results in many hits. Thus Dutch readers were confronted with words denoting or connoting Europe in their newspapers far more often than Table 26.1 suggests. Nevertheless, searches for England or France indicate that 'Europe' appeared in Dutch news media far less than the names of important European powers of the time. Hence the results for 'Europa' are put into perspective in Table 26.1 by comparing them with those of Portugal, a less newsworthy state in Dutch media reports. ${ }^{18}$

18 Total figures for the Dutch variants for England, 'Engeland' and 'Engelant', seventeenth century: 4,914; and eighteenth century: 49,002. This text retrieval should be broadened with all Dutch variants of Great Britain. Figures for only the variant 'Groot Brittannien', seventeenth century: 532; and eighteenth century: 25,656. Total figures for the Dutch 
Although the above results are not very impressive, they prove that Europe was visibly present in the newspapers. In what context, and with what meaning, was the word used in the news? It is not surprising that the geographical notion of Europe as a continent was the most common meaning. ${ }^{19}$ There are many references to Europe in news items about trade and travel between this continent and other parts of the world, or about merchant vessels in European harbours. During the first Anglo-Dutch War, for example, the Dutch StatesGeneral ordered all Dutch shippers not to enter ports under English control "in and outside Europe" to avoid their ships' being confiscated. ${ }^{20}$

Europe as a geographical entity was even more frequently mentioned in news reports about international politics, in which editors summarised the state of affairs in Europe, its major powers, states, princes, courts, wars, treaties and so on. On 11 October 1672, for instance, an Amsterdam newspaper reported a message from Paris expressing the expectation that if "the troubles of Europe" were to continue, one or more German electors would be deposed and replaced. ${ }^{21}$ The idea of a European balance of power was reflected in an account from Italy, included in the Haarlem newspaper of 5 December 1673 , which mentioned the Papal Court's wish "also gaerne soude sien, dat Spangie den Staet van Europa soude balanceren, ende de grootsheyt van Vrankrijck wat verminderen" ("that Spain would balance the state of Europe, and diminish France's grandeur a bit"). On the other hand, according to a letter from a French archbishop, sent to the pope and summarised in the Haarlem newspaper on 1 April 1681, the phrase "dat in Europa niet een Prins is, die hem [i.e. 'den Turck'] kan tegen staen, als alleen de Macht der Franssen" appeared ("only the Power of the French could resist the Turk[s] in Europe"). In August 1684 peace "across

variants for France, 'Vran(c)kry(c)k', 'Vranckrij(c)k', 'Franckry(c)k' and 'Frankrijk', seventeenth century: 785 ; and eighteenth century: 122,034. The results of OCR technique are not $100 \%$ trustworthy, therefore all these figures should be considered as approximations. See $<$ www.delpher.nl $>$ [04/11/13].

19 For reasons of feasibility the text retrieval is restricted to the noun 'Europe' in the digitized seventeenth-century Dutch newspapers. A few samples in eighteenth century copies do not give rise to the idea that 'Europe' had developed different meanings from those found in seventeenth century newspapers; in contrast to today when 'Europe' has become, e.g., a synonym of the European Union.

Ordinaris dingsdaeghse (Tuesday) courante, 6 August 1652. See also, e.g., Haerlemse Courant, 26 March 1661; Ordinarisse middel-weeckse courante, 5 December 1662; Amsterdamse Courant (AC) 18 July 1686. Newspaper editions are not repeated in footnotes when they or the discussed news items are mentioned in the main text.

21 In Dutch: "Men seght dat soo de Troebelen van Europa souden mogen continueren, wel eenig Keur-Vorst soude werden ghecasseert, en een ander Prins in sijn plaets werden ghestelt". 
the whole of Europe" was expected in letters summarised by the Amsterdam newspaper editor, as soon as the king of France accepted the same conditions to which his Spanish counterpart had agreed. ${ }^{22}$

Furthermore, Europe was considered a unified geographical entity in a handful of news accounts emanating from the continent's periphery. For instance, an excerpt of a letter from Persia was published on the 4 June 1669 Haarlem newspaper, stating that "Men verwacht hier de voornaemste Tijdinghen uyt Europa" ("the most important tidings from Europe") were expected. In another example, a message from Smyrna (now Izmir) in Turkey in an Amsterdam newspaper of 1 March 1674 begins with the sentence: "De groote Oorlogen van de Christenvorsten in Europa, veroorsaken hier seer slappe Negotie" ("The great wars of the Christian princes in Europe cause a very weak trade here"). ${ }^{23}$ It is interesting to note that the report speaks about Christian European princes, probably in order to draw a contrast with the Islamic Ottoman Sultan, who ranked himself as one of Europe's princes. The Turkish war declaration against the king of Poland, for instance, published in the 15 March 1621 issue of the Tijdinghe uyt verscheyde quartieren (Tidings from various quarters) starts with a list of some of the Sultan's many titles, one of which in particular must have been rather confronting for the Dutch readers: "Regeerder van 't gantsche Christenrijk ende Europa" ("Governor of the whole Christian empire and Europe").

'Europe' also appeared in its geographical sense in contexts having to do with persuasion and comparison. A news item of 2 September 1673 in the Haarlem newspaper states that new fortifications would make Turin one of the most beautiful cities in Europe. Such a comparison sounded, of course, more impressive than a comparison limited to other Italian cities. This is also the case with a news report in the Amsterdam newspaper of 27 March 1692 suggesting that the Duke of Savoy would have been Europe's happiest prince had he not started the war. ${ }^{24}$

Europe as a geographical entity was also used in a great number of advertisements for books and periodicals about Europe's history or its state of affairs.

22 In Dutch: "soo dat men niet en twyfelt of den Koninck van Vrankryck sal dese conditien mede accepteeren, en dan staet men door geheel Europa in korte eenen Generaelen vrede te hebben". AC, 3 August 1684. See also, e.g.: Oprechte Haerlemse Courant (oHC), 16 January 1672, 7 April 1672, 28 May 1672, 10 October 1673, 26 September 1675, 7 June 1678 and 3 July 1688; Utrechtse courant, 23 April 1691; AC, 9 November 1683, 8 June 1690 and 22 November 1692; Opregte Leydse courant (OLeyC), 25 April 1698.

23 See also, e.g.: $A C, 14$ September 1688; OLeyC, 21 March 1698.

24 See also, e.g.: $O H C$, 23 June 1663 and 31 January 1696. 
An early example can be found in the 30 March 1630 issue of the Courante uyt Italien, Duytslandt \& $\&$ in which the seventeenth volume of Nicolaas Jansz van Wassenaer's history of Europe and other parts of the world was announced. ${ }^{25}$ An advertisement concerning a periodical is Jan Bouman's announcement for De reysende Mercurius verhandelende de hedendaegsche en onlangs tegenwoordige staet en verrichtingen van Europa (The travelling Mercury treating the contemporary and earlier state and activities of Europe), published on 22 December 1674 in the Amsterdam newspaper. ${ }^{26}$ Such advertisements remind us that a market existed for publications concerning Europe as a whole.

Finally, a very distinctive - and non-geographical-meaning of Europe in early modern Dutch newspapers concerns reports about ships bearing the name of 'Europa' or 'Nieuw Europa'. Several ships of the Dutch East India Company bore these names, a few Dutch slave ships going to the West Indies were christened 'Europa', and the Haarlem newspaper's issue of 4 December 1677 also mentions a French ship called 'Europa'. All these ships generated many news items about their movements between harbours and sometimes about their cargoes. ${ }^{27}$ Such ships popularised the idea of Europe as one continent directly through their names and indirectly through their movements both in and outside Europe. As the newspapers included only neutral facts about them, news items about ships called 'Europa' can be considered as an unintended consequence of the popularisation of the idea of Europe.

\section{Argument Three: News about Europe in a Eurocentric Layout}

From the beginning Dutch printed news media included information from all corners of Europe. In other words, they created a sense of Europe because most of the news reports dealt with European affairs. Due to distance and the

25 The advertisement in Dutch: "Dese weke is uytghegheven by Ian Iansz het 17. Gedeelte, oft Vervolgh van het historisch Verhael aller Ghedenckwaerdig Ghesichedenissen, soo in Europa, Asia, etc. voorghevallen zijn; Beschreven door Nicolaes à Wassenaer".

26 See also, e.g.: OHC, 2 August 1667, 22 January 1675, 23 May 1675, 3 January 1682, 6 January, 13 and 20 April, and 24 February 1688, 1 March 1689; AC, 30 December 1677, 29 March 1691, 10 April and 21 October1692, and 3 May 1698.

27 See, e.g.: OHC, 2 August 1667, 22 October 1669, 3 March 1671, 18 April 1673, 4 December 1677; AC, 21 October 1673, 1 May 1677, 21 December 1686. See for the voyages of the Dutch East India Company ship Europa the website 'Dutch Asiatic shipping in the seventeenth and eighteenth centuries', <www.historici.nl/Onderzoek/Projecten/DAS/> and for slave ships with the name Europa the Website <http://slavevoyages.org/tast/database/search.faces> [03/05/15]. 
lack of regular communication, information about other parts of the world would remain scarce until the nineteenth century. Furthermore, news from outside Europe was mainly restricted to areas in which European colonies and trade posts were situated or where Europeans were involved in warfare. Dutch news media had, in addition, a distinctly European character, as domestic news occupied relatively little space in the news columns before the second half of the eighteenth century. Most local news was still orally dispersed, since oral transmission remained more efficient than print publication until the dailies came into existence. Furthermore, domestic news was mostly restricted to government documents, announcements and politically uncontroversial messages, as Dutch news editors tried to avoid censorship. Therefore, news from abroad, from other European countries, dominated the Dutch news media. ${ }^{28}$ All accounts on foreign topics must have expanded the average Dutch readers' knowledge of their continent immensely.

The layout of most early modern Dutch newspapers and periodicals enhanced the sense of Europe in the news. From around 1650 readers' attention was drawn to reports published under the headings of European state names. In 1656 the Haarlem editor Abraham Casteleyn adopted this practice in his Weeckelycke courante van Europa. Other Dutch newspapers began to follow suit from around $1662 .{ }^{29}$ This also serves to explain why the names of individual countries, such Germany, France and England - or Great Britain from 1707-occurred much more frequently in the news media than the continental name of Europe since the 166os. Most of the time editors opened their publications with news from the countries geographically furthest from the Dutch Republic, typically moving on to states closer to home and ending with domestic reports under the heading 'Nederlanden' (The Netherlands), very often on the back page. There would be one or more news items under each heading, usually in chronological order and starting with a dateline consisting of the news item's city and date of origin. The Friday 10 April $175^{\circ}$ issue of the Opregte Groninger Courant (Sincere Groningen Newspaper) can be considered typical of Dutch early modern newspapers (see Figures 26.1

28 Marcel Broersma, 'Constructing public opinion: Dutch newspapers on the eve of a revolution (1780-1795)', in News and Politics in Early Modern Europe (1500-180o), ed. Joop W. Koopmans (Leuven: Peeters, 2005), pp. 219-35, at 223.

29 Before the 1660 s news items mostly appeared under the headings of city names. The 26 August 1656 Weeckelycke courante van Europa is the first digitised issue with states as headings. <www.delpher.nl $>$ [05/11/13]. The $175^{2}$ starting Leeuwarder Courant would be the first Dutch newspaper with a thematic approach, by making sections such as 'state news', 'trade', 'church news' and 'accidents'. 


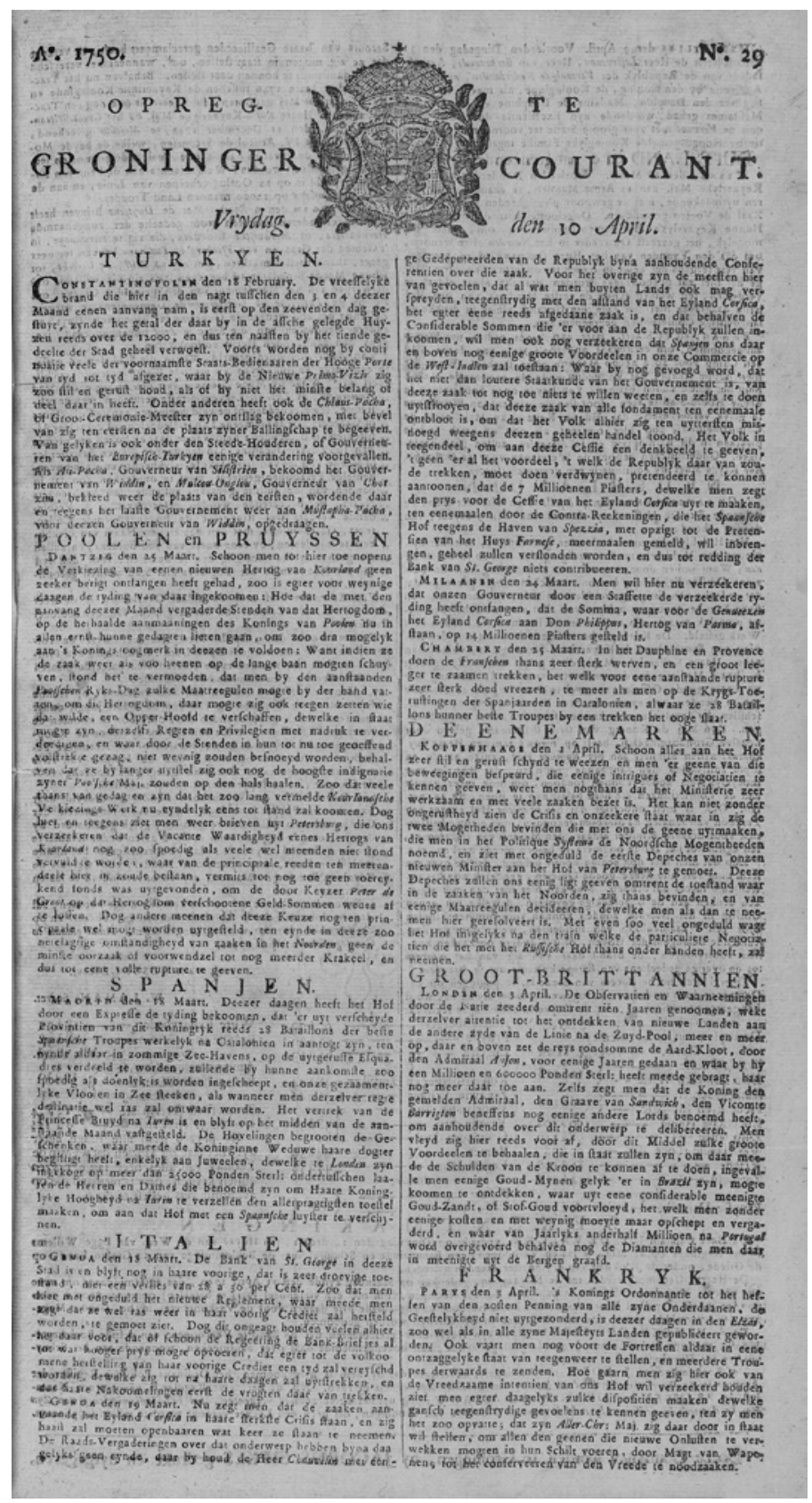

FIGURE 26.1 Front page of the Friday 10 April $175^{\circ}$ issue of the Opregte Groninger Courant, with news under the headings of Turkey, Poland and Prussia, Spain, Italy, Denmark, Great Britain and France UNIVERSITY LIBRARY GRONINGEN. 


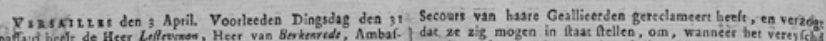

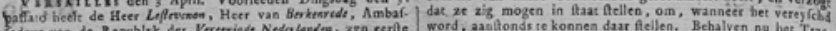

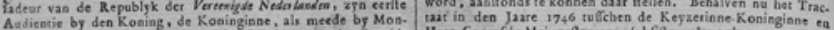

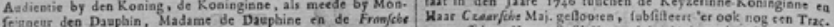

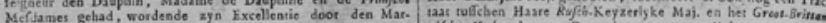
quis de Verraat met zeer groote Statie ter voornoemde Audien- nijchr Hot, den "I Decermber 1743, to Moferw geteckend,

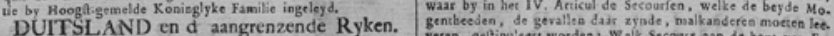
W axkse den as Maart. Voorleesen Donderdag beete zyo Xefzerlyke Maj, 2an 12 Arme Mannen, te zamene $109^{3} \mathrm{Jah}$. ren uyrmakkendo, met de gewoone plegrigheeden in de Ridder-
Zas de Voeten gewaffesen. Ongelooffelyk is de moeyee die Hanne Keyzerlyke Majefteyien aiawerdea, om, wasre he mogelyk, bet gerreet Oaweeder in ber Nourden af te wenden,

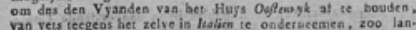
van yeur leegens het zelve in liakien te ondervecemen, zoo lan

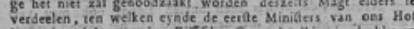

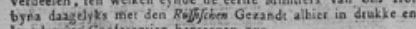
langduarije Conferentien begreepen $25 n$.

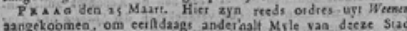
eetr Camp yoor 10 a 25000 Manne, at un Atecken. Waar yy men hoope fctiept, dat wy gederitende de azallande Mase May bet gelak zulien hebbes, van beyde ooze Souverainen

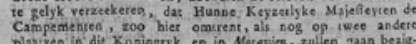

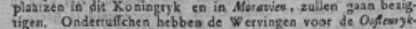
feri Kityg- Magr by coatineatic een gewerfcht fusser.

N E D E R L A N D E N

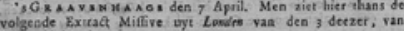

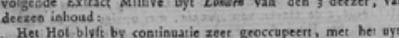

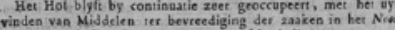
diw, Want indien door eene aan een fchaskeling van onvoor-

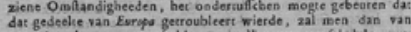
onze kantber geaotgen bebben van alles wat menfebelyker wy. 20 mogelyk, waare, om zulks voor te koomen, te hebben in
Werk getteld. De Koniag is het weegens dit point mer den Ko ning vap Framiryk en de Keyzerime. Koningiene, volkoom eens. Hase Keyzerlyke Ma). die, gelyk meermialen gere is, baste Mediatio in deezen heetr aangeweed, tar nog nic an te wenden, les ejnde die twee Kroonen weegens de Ver fchillen die dezelve zouden konoen. fcheg deh, over een te biea:

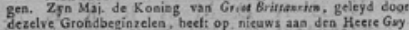

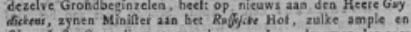

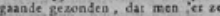

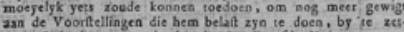
ven. Ook is men onderrigit dax het Freyfobe Hot expres ce Perzoon van ainzien na Sioktown gezonden, met niegure Inftruc

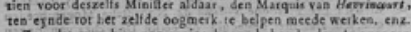
Zoo dat mes hiet nog eenige hoope behoud, dar de over eep feancing van alle deceze gocsec Offcien, cypdelyk nog her ge wenfche facres zal bebben. Mea kan hier niet das met algry.
zen denkeri an de ougelakkigo gevolgen, dewelke oyt eenen zen denkeri an de oggelakkige gevolgen, dewellke uyt cenen door een itzamenloop van incísen en, welke door de Vernea voortiloeyen, de brand dar vas $21 g$ van bet Neorden

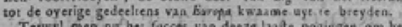

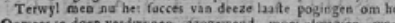
Oaweer ce doen verd́wyaen, asagewend, moet atwazen, word

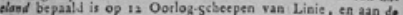
zyde vas Rafara op 12000 mannen Laad. Trowpes. Gxosino an den 9 April, Met de Dastjabe Brieven heete

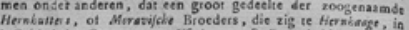

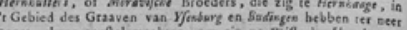
gezet, thans toeftel maakien, om ziç na zith, by Circkit, toe Munne Meede-Rhoederen ie begeeven, als zig nist willende onderwerpen asa het Mandegrent van den gemelden Grave, ort

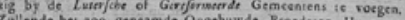
Zaliende her zoo genaande Oagthuwde kroederen Hujs, en cens den a Van Amperdan word gemeld, dat in die Sad den ar para. to een zeer nadrakkelyke en erndige Was/ecertsting gepubli.

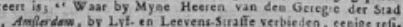

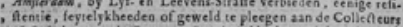
" of Gairders ran de Gemeene Lands. Middelen, of derzelver AS. "Giftenten en Bedienden: Beloovende dasi en boven een premie ". van 100 Zilvere Ducatons, aan den geenen die een Aanvoerdet ". gemelde Perzoonea geplectgt, weet le onidekten an doo dat in handen van de Jentiale geraskis zullende des hanbiengers

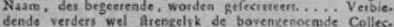
"reurs, Gaarders enx. met den haselyken Naaga vas verkliz. kers te injarietren, by eene boete van 300 Galders y en zullen die geene, welke onmagig zyn te betasien, voor den tyd van zes Maaden in bet Togihuys dier Siad worden geconti. neen.

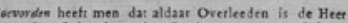

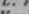

Vegge. gende Pebsceris yan we April. Men ziet bier weer de rol.

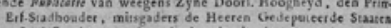

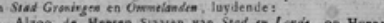
Edele Mogende Vetzadeting van den 28 Mast jongh ondet anderen bebben gordgeronden das, om voor to koomen de meenigvuldige Mlagron welke van tyd sot tyd door de Kooplieden bandei dryvende in de Waren onder Kramerye bee pro Cesto, op gemelise Gosderen gelegt, als nadeclig roor de Commercie, te fupprimerten en op te heffien. , $\mathrm{Z} 00$ is ' $\mathrm{T}$, dat $\mathrm{W} y$ hebben noodig geoordeeld dart

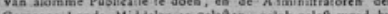
Gemeene Lands. Midjelea te gelaten, gelyk gelaft word by

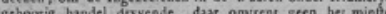
" molen te doen, nas genetsen Hadel, zoo wel als de Zoete en Nurembrager Waren, viy ea onveibinderd te lasien

En op dat zulks tot een yeders keaniffe moge koomen, za!
En deezen door de gelicele Provistie worden gerobliceert en op Grearingen dew 2 april inso.

J. VAXGESSELER vi.

w. LAMAN, Sectet:

bet geruge gecontirmeert, dat de Keyzetin Ailer. Rojer reeds het

De Pryien van de Giaprinn zyn

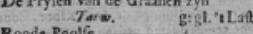

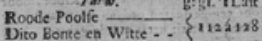

Koningsberger Heuge en Eibingle —

Heugre en Eibingle - S 106 á 116

Engelifche roode__ 902102
Dito wite
82110

Vooriandfe roode
Vriefle

Zeeawfe $--7-1142126$

Bruyne -

ingetfe - - 64270

Keningberger ep Dantefiker - 48254

reuwle Wister

oorlandic dito -.t.

Vriefic dito . 38 á 58

Zomer

Hever. $44+54$

62 272 Brouw Veer $\square\} 3+242$

Witte Eydervoeder - 18232 bruyne co Swarte - $-\bar{V}-18$ à 33

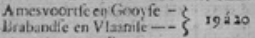
Boiken. Zecunfeen Orcriniatc $-113 \hat{j}_{14}$ Groninger en trice - 9212 De pryzen gain aile darge agtce Zooner vain alles bices lase pryzen zulten lorgen, dasi is nicmand die op avontnur yets gelicfis te doen,

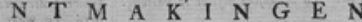

De Heer Capiain J. B. DE V A LC K E. gederke op Diogsdag den 14 deezer, ten Hurze van de Wed. van Egee willemi in het Regthays op de Mie, te Lasitn Verkoopen, een Mehingziege en Schuere, met de Bekleaiminge van 30 Grafen Land, ep de Griese. onder de Kloktag van Uyihayiter Meeden geleegea.

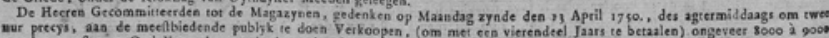

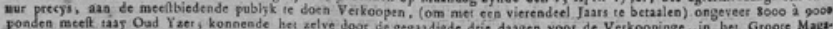

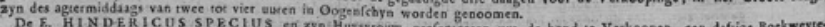
Moolen met aya toebehooretl. Jemabds gadiage zyade, kan bovengeneeren uys de hand te Verkoopes, een deffige Boekweyte

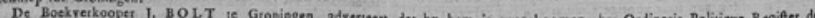

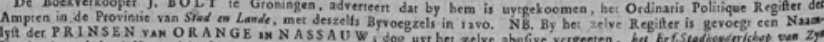

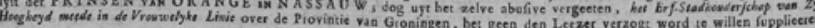

Deeze Couranten worden te Groningen, by JACOBUS SIPKES gedrukt en uytgegerte

FIGURE 26.2 Back page of the Friday 10 April $175^{\circ}$ issue of the Opregte Groninger Courant, with the rest of the news from France, continued by news under the headings of Germany and neighbouring empires (in this case news from Vienna and Prague) and the Netherlands, finally followed by advertisements and production notes UNIVERSITY LIBRARY GRONINGEN. 
and 26.2). This issue opens with news from Turkey on 18 February and ends with a message from Groningen of 9 April. The system could be changed, however, to allow for late-breaking news reports. These would be published under the heading 'Netherlands' and with a dateline starting with the name of the newspaper's city.

This model of layout may have stimulated Dutch newspaper readers to start with foreign news, assuming they began with the first or front page (though this remains necessarily uncertain). At all events, readers became gradually more aware of Europe's map, the distances between the Dutch Republic and other European countries, and geographical changes caused by international politics. For example Dutch newspapers began using the heading 'Great Britain' rather than 'England' after the 1707 Act of Union between England and Scotland. ${ }^{30}$

News periodicals such as the 1690 Europische Mercurius and the 1756 De maandelykse Nederlandsche Mercurius (The monthly Dutch Mercury) intensified the European character of Dutch news media by following a similar form of geographical sequencing of items as the newspapers. Although Europe featured in the latter periodical's subtitle as a news area, it is significant that its first volume's monthly sections began with a few news items under the headings of other continents ('Azia', 'Noord America', 'Africa'), followed by the heading of 'Europa', under which heading, it should be noted, Turkey is the first European country to be mentioned..$^{31}$ The layout of the eighteenth-century periodical confirms the idea that Europe and Christianity could no longer be considered as synonyms by that time.

\section{Argument Four: The Presence of Europe in News Prints}

Europe as a continent was not only present in the texts of early modern news media, but could also be found in news prints that referred to European news topics. Such prints could be published and sold separately as well as included in news periodicals or pamphlets with a production schedule that was long enough to accommodate them, thus not in newspapers with a short periodicity. These prints' share of the overall news market was modest; nevertheless, they should not be altogether left out of this discussion of the sense of Europe in

\footnotetext{
$30 \quad$ See, e.g.: OHC, 21 and 23 June 1707; OLeyC, 20 and 25 June 1707.

31 De maandelykse Nederlandsche Mercurius, geevende een volledig bericht van alles, wat'er aanmerkenswaardig ieder maand, in Europa is voorgevallen (The Dutch Monthly Mercury Giving a Complete Report of All Important Events in Europe), no. 1 (1756).
} 
Dutch news media. News prints making reference to European news topics undoubtedly intensified a sense of Europe by making those subjects, such as wars and peace, more concrete or understandable. News engravings had similar functions to today's photographs in news media. They would attract and inform readers by representing people, buildings, statues, events and everything else that could be sketched. They would also reflect contemporary societal ideas and views.

However, in contrast with news photographs, early modern news illustrations - in the form of woodcuts or engravings - were, by definition, artists' impressions, merging facts and fiction. ${ }^{32}$ This could be the result of ignorance, or a deliberate way of achieving a particular effect: a simplification of the actual circumstances, for instance, or the presentation of a series of news events in a single picture. The use of symbols and allegorical figures derived from Europe's ancient past was very common. In many news prints Mars and Pax figured as simple allegories indicating the state of European or local affairs, or to supply a readily graspable context for peace negotiations. Such allegorical representations may be considered as typical products of European culture, easily understood by an educated contemporary audience. News prints were not subject to language barriers, apart from specific plays upon words. Yet even when vernacular phrases were included, many Europeans got the message. Other artistic forms, such as paintings and sculptures, stimulated this general European understanding, since they used the same visual language. ${ }^{33}$

Within the context of this chapter the mythological Princess Europa is the most important such figure, since she gives rise to the continent's name. Her kidnapping by Zeus in the guise of a bull and her removal to Crete inspired artists throughout European history in a variety of genres. ${ }^{34}$ The frontispieces with Princess Europa and Zeus in the above-mentioned Europische Mercurius belong to the most prominent Dutch examples in the field of news prints.

32 A comparison between today's cartoons and early modern news prints is also possible considering the fact that both genres are drawings. In cartoons, however, the role of irony is central.

33 See, e.g., Joop W. Koopmans, 'Politics in title prints: Examples from the Dutch news book Europische Mercurius (1690-1756)', in Selling and Rejecting Politics in Early Modern Europe, ed. Martin Gosman and Joop W. Koopmans (Leuven: Peeters, 2007), pp. 135-49, at 135-40 (including bibliographical references).

34 Many examples can be found in Michael Wintle, The Image of Europe: Visualizing Europe in Cartography and Iconography throughout the Ages (Cambridge: Cambridge University Press, 2009). 


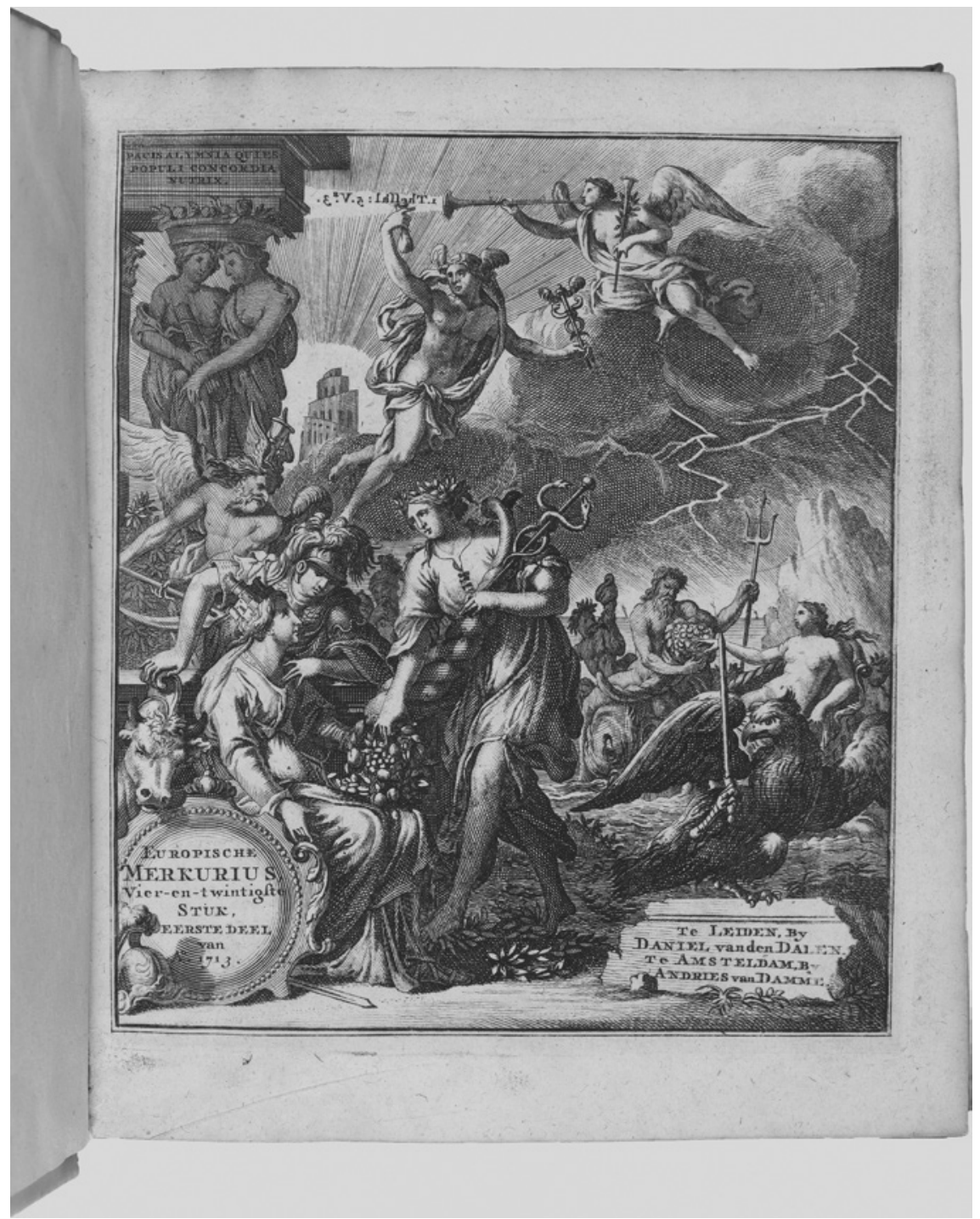

FIGURE 26.3 Frontispiece of the Europische Mercurius from 1713.

UNIVERSITY LIBRARY GRONINGEN

Princess Europa and also Mercury, the messenger of the gods, are present in most of the periodical's frontispieces, which feature news topics from the corresponding volume.

To exemplify the genre, the anonymous 1713 frontispiece of the Europische Mercurius (see Figure 26.3) — probably made by the engraver and author Jan 
Goeree ${ }^{35}$ - should suffice here. It refers only to one news item: the Treaty of Utrecht, or, more precisely, the series of peace treaties that ended the War of the Spanish Succession, in which many European countries had been involved since 1701. France would sign separate agreements with, respectively, Great Britain, the Dutch Republic, Savoy, Prussia and Portugal in the Dutch city of Utrecht on 11 April 1713.

The print, however, does not show diplomats who are signing treaties. The central figure is Pax, who treads on the laurels of war heroes. She delivers the horn of plenty to Princess Europa, sitting on a bull whose head is visible. Pax's dress has pegs and eyelets, in reference to the Dutch saying 'haken en ogen', meaning problems; in this case surely a reference to the difficulties of the peace negotiations. The goddess Minerva, still wearing a war helmet, warns Princess Europa that the peace is unstable and may soon be broken. The figure of Time, with the traditional hourglass on his head and scythe in hand, illustrates the fragility of the situation. Near the sea god Neptune's a nymph floats quietly, symbolising Great Britain. The eagle, on the other hand, holds a military baton, symbolising the German Emperor whose campaigns against France were ongoing.

In the meantime Mercury - the figure with a winged hat and a caduceustravels to other countries to catch new messages. The rising sun illustrates hope, while the Tower of Babel and Pheme stand for uncertainty about the duration of the peace. Pheme shows her doubts by trumpeting a biblical reference, 1 Thessalonians 5:3 ('For when they are saying, 'Peace and safety', then sudden destruction will come on them, like birth pains on a pregnant woman; and they will in no way escape"), in mirror image. ${ }^{36}$ In front of her two other female figures hold a box that may contain the peace treaties; they support a building inscribed with the Latin words "pacis alumnia quies populi concordia nutrix" (rest is the child of peace [and] the population's harmony is its foster mother). The reference to a bible verse and the use of a Latin quote are also characteristic examples of European cultural expressions of the time, next to all mythological figures.

In 1738 the Europische Mercurius would include another frontispiece of Pax and the Peace of Utrecht, in celebration of twenty-five years of peace in the Dutch Republic. ${ }^{37}$ However, the next European war-the War of the Austrian

35 At any case Jan Goeree (1670-1731) wrote the corresponding frontispiece's explanation on rhyme. See further: Joop W. Koopmans, 'Jan Goeree en zijn ontbrekende titelgedichten in de Europische Mercurius (1713, 1718, 1719 en 1727)', Mededelingen van de Stichting Jacob Campo Weyerman, 26 (2003), pp. 73-90, at 73-81.

36 Quote from World English Bible (2002), <ebible.org/> [03/05/15].

37 See also David Onnekink and Renger de Bruin, De Vrede van Utrecht (1713) (Hilversum: Verloren, 2013), pp. 101-105. 
Succession-followed soon after, producing prints of news events that would become the next part of a shared European past.

\section{Conclusion}

This chapter shows that early modern printed news media stimulated a sense of Europe in the Dutch Republic, though mostly implicitly and not necessarily on purpose. Nonetheless, news media surely helped to shape Europe as a reality, particularly in the minds of its inhabitants who did not or could not see other parts of the continent with their own eyes. By presenting and structuring European affairs in pieces of news, and positioning or explaining them in a European context they also created a European audience, one admittedly divided by wars, religious controversies and conflicts, yet possessing certain shared interests, aims and expectations. Dutch news editors translated and adapted foreign news letters and newspaper items, presenting Dutch news readers much the same news as was available to people abroad. Furthermore, Dutch media not only affected the Dutch reading population but also other parts of Europe as they were translated and read elsewhere. The need for news stimulated and intensified news networks across Europe, making a European news market.

Four coherent arguments have been discussed to reflect on the questions how early modern Dutch news media may have contributed to the creation of a sense of Europe, and in which ways they made the idea of Europe more familiar to their readers. The first two of them dealt with the use of the words 'Europe' or 'European' in the titles of news media and its contents. They can be considered as indications that the notion of Europe was indeed current. The third argument demonstrated that news media mostly offered European news through particular geographical configurations of layout. This was visible in most issues of most newspapers, as well as in many news periodicals. This last argument is the most important. Finally, I have shown how Europe was also present through visual language, by using European symbols and figures in news prints. Considering all four arguments together adds resonance to Aristotle's phrase, 'the whole is greater than the sum of its parts'. This ancient Greek axiom may be considered as the fifth argument to show how, from news about Europe's internal conflicts, a unified sense of Europe emerged in the early modern period. 